\title{
Tips Dan Trik: Mengenali Tamponade
}

\author{
Rina Ariani, Amiliana M Soesanto
}

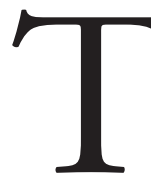

amponade merupakan kondisi klinis mengancam jiwa dimana fungsi jantung terganggu oleh penekanan dari ruang pericardium, baik oleh cairan, massa, bekuan darah, ataupun kombinasi antara ketiganya. Fisiologi tamponade terjadi akibat terganggunya hemodinamik akibat peningkatan tekanan intra pericardium sehingga mengganggu pengisian ruang jantung. Tamponade dapat terjadi akibat adanya volume efusi yang cukup besar atau terbentuknya efusi dalam waktu yang singkat. Perlu diingat bahwa efusi yang besar dapat tidak menimbulkan tamponade bila terakumulasi bertahap sehingga memungkinkan rongga perikard meregang dan beradaptasi. Harus pula digaris bawahi diagnosis tamponade merupakan diagnosis berdasarkan klinis namun ekokardiografi seringkali dapat mengenali adanya tamponade dengan lebih dini.

\section{Gambaran ekokardiografi tamponade}

\section{D Echo}

1. Visualisasi efusi pericardium. Efusi dapat berupa efusi ringan terlokalisasi sampai dengan efusi masif dengan gambaran 'swinging heart'. Pandangan

\section{Alamat korespondensi:}

Dr. dr. Amiliana M Soesanto, SpJP, Departemen Kardiologi dan Kedokteran Vaskular FKUI, Pusat Jantung Nasional Harapan Kita. E-mail: amiliana14@gmail.com
2D dan $\mathrm{M}$ mode merupakan baku emas dalam mendiagnosis adanya efusi pericard.

2. Kolaps ventrikel kanan saat fase diastolik amponade tekanan intraperikardium melebihi tekanan di intrakardiak, sehingga akan menekan RA dan RV, dan menimbulkan kolaps RA pada fase diastolic akhir, dan RV pada fase diastolik awal, sesuai dengan fase dengan tekanan terendah dalam ruang-ruang tersebut. Dengan semakin beratnya tamponade, kolaps RA akan timbul semakin awal pada pase diastolik, dan kolaps RV akan bertahan sampai fase diastolic akhir. Kolaps RA merupakan temuan sensitive untuk meningkatnya tekanan intraperikard, sedangkan kolaps RV lebih spesifik untuk tamponade.

3. Dilatasi IVC tanpa variasi inspirasi

Peningkatan tekanan atrium kanan akan menyebabkan dilatasi dari IVC dan hilangnya variasi inspirasi dan ekspirasi. Hal ini dapat dilihat daripandangan $\mathrm{M}$ mode-supxyphoid long axis.

4. Meningkatnya interdepedensi ventrikel terhadap variasi respirasi.

Adanya efusi pada rongga pericardium me nyebabkan ruang-ruang jantung memiliki kapasitas yang terbatas untuk meregang pada saat fase diastolik dan akan meningkatkan interdependensi interventrikel. Saat inspirasi, tekanan negatif rongga intratorakal akan menyebabkan darah 

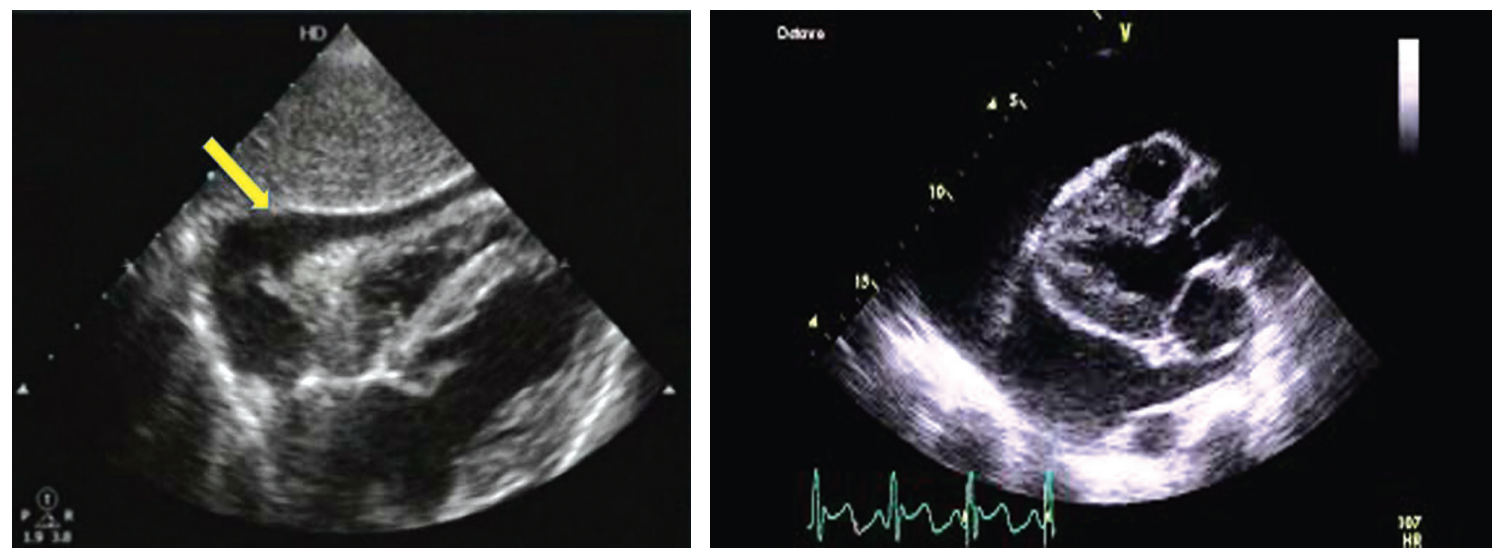

Gambar 1.Gambaran efusi pericardium yang relatif terlokalisasi pada sisi lateral RA dan RV pada pasien pasca operasi (kiri), dan gambaran efusi pericardium massif dengan 'swinging heart' (kanan).
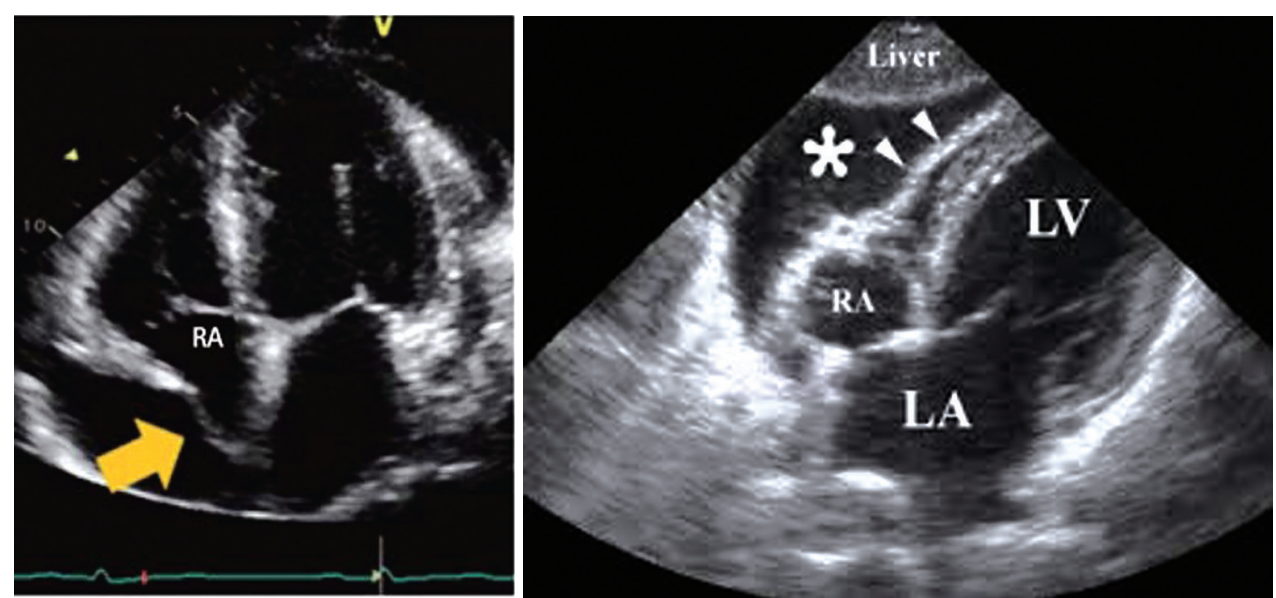

Gambar 2. Tampak kolaps RA pada fase diastolik akhir (kiri, panah kuning), dan kolaps RV pada efusi yang terlokalisasi (kanan penunjuk segitiga).
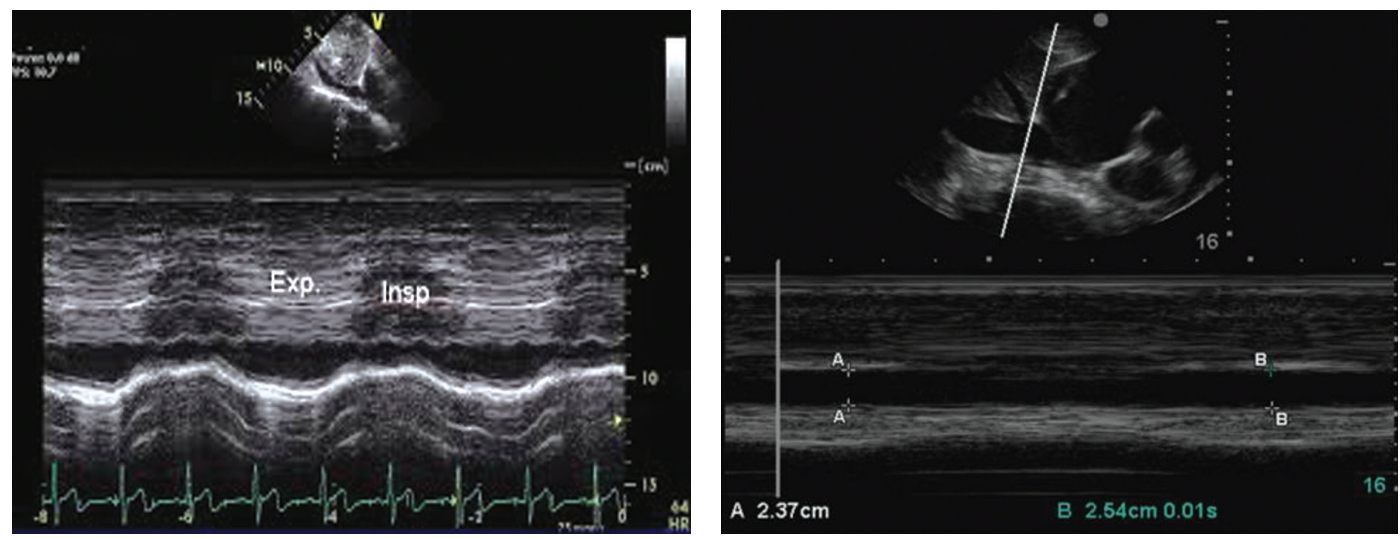

Gambar 3. Gambaran IVC pada pasien normal (kiri) dan dilatasi IVC tanpa variasi respirasi pada pasien dengan tamponade. 


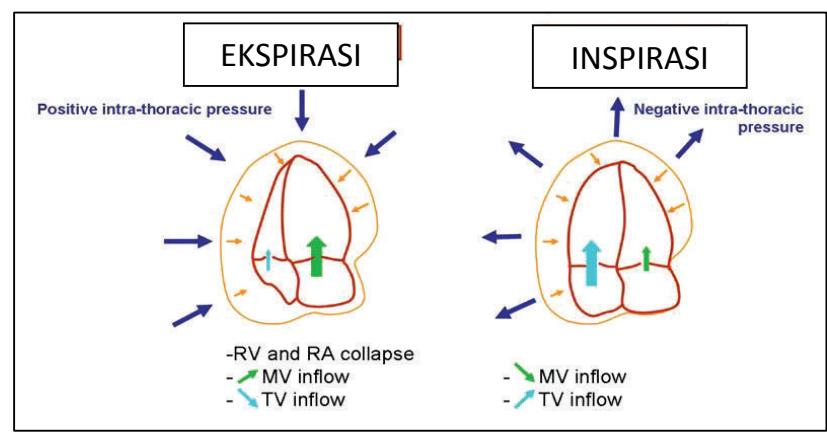

Gambar4. Mekanisme terjadinya interdependensi ventrikel saat tamponade (dimodifikasi dari http://www.stanford.edu/group/ ccm_echocardio/cgi-bin/mediawiki/index.php/Tamponade)

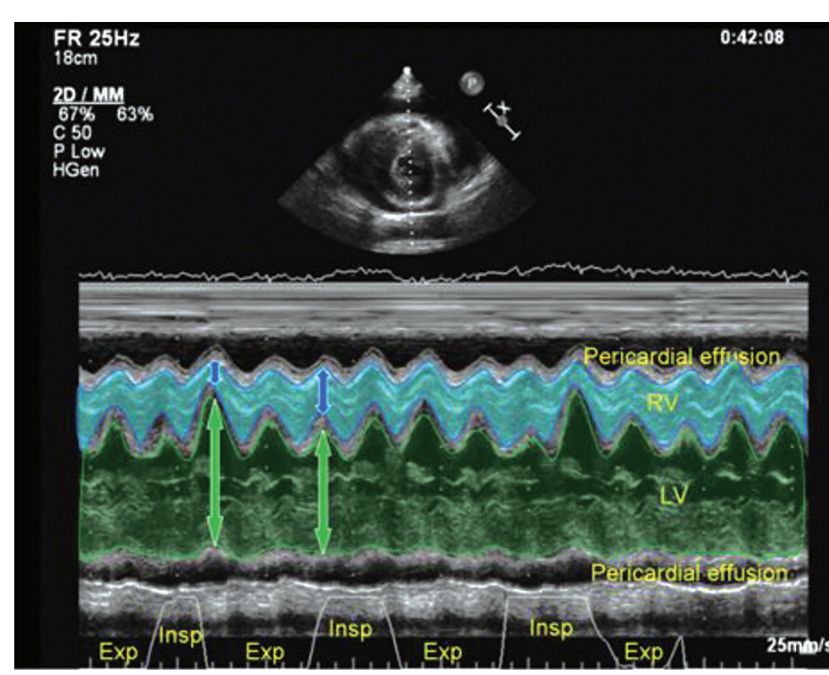

Gambar 5. Pandangan parasternal short axis $M$ mode yang menggambarkan interdependensi ventrikel yang diperngaruhi respirasi (diambil dari http://www.stanford.edu/group/ccm echocardio/cgi-bin/mediawiki/index.php/Tamponade)

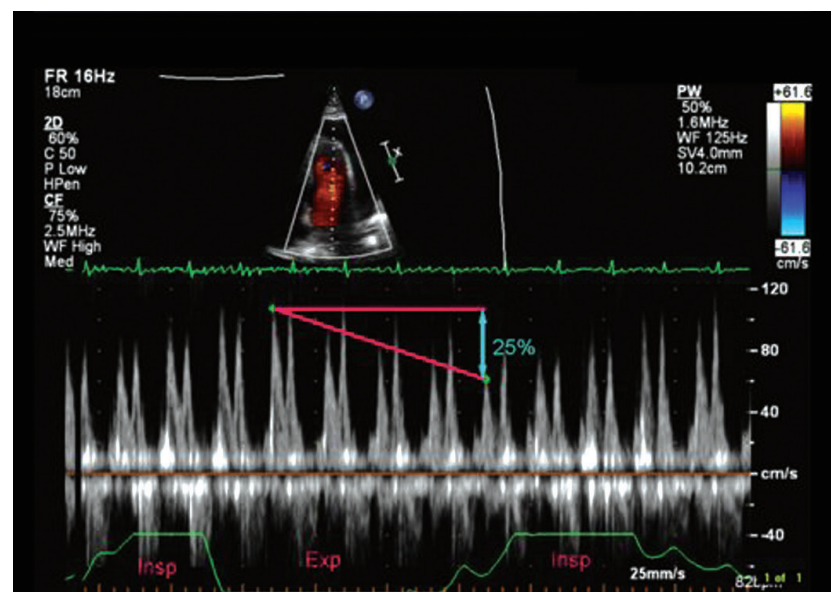

Gambar 6. Gambaran Doppler pada mitral inflow menunjukkan variasi respirasi yang lebih besar dari $25 \%$ masuk ke atrium kanan dan ventrikal kanan sehingga volume ventrikel kanan akan bertambah, dengan konsekuensi mengecilnya volume ventrikel kiri. Pada saat ekspirasi, akan terjadi kebalikannya, dimana tekanan intratorakal menjadi lebih positif, darah dari paru akan masuk ke ventrikel kiri, dan menyebabkan volume ventrikel kiri akan bertambah dan ventrikel kanan akan mengecil. Pada ekokardiografi hal ini dapat dilihat pada pandangan $\mathrm{M}$ mode baik parasternal long axis maupun parasternal short axis.

\section{Doppler Echo}

1. Variasi mitral/tricuspid inflow $>25 \%$

Variasi respirasiab normal dalam fase pengisian ventrikel (fasediastolik) bermanifestasi sebagai pulsus paradoksus, fenomena ini dapat pula dinilai dengan menggunakan Doppler echo dengan melihat aliran melalui katup mitral dan tricuspid. Variasi mitral/tricuspid inflow > 25\% menunjukkan adanya tamponade.

\section{Daftar Pustaka}

1. Maisch B, Seferovic PM, Ristic AD, Erbel R, Rienmüller R, Adler Y, et al. Guidelines on the Diagnosis and Management of Pericardial Diseases Executive Summary. Eur Heart J, 2004.25 (7): 587-610.

2. Jung HO. Pericardial Effusion and Pericardiocentesis: Role of Echocardiography. Korean Circulation Journal, 2012. November; 42(11)725

3. Pepi M, Muratori M. Echocardiography in the diagnosis and management of pericardial diseaseJournal of Cardiovascular Medicine 2006. 7:533-544 